\title{
Microbial Etiology of Cancer
}

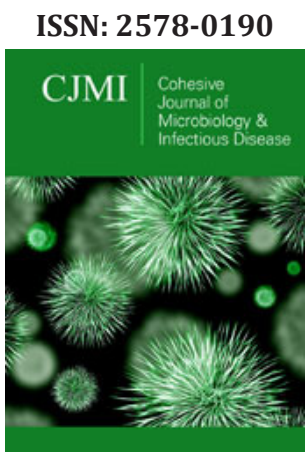

${ }^{* 1}$ Corresponding author: Mosab Nouraldein $\mathrm{MH}$, Department of Medical Parasitology, Sudan

Submission: 酸 December 30, 2018

Published: :-1-narch 22, 2019

Volume 2 - Issue 4

How to cite this article: Mosab Nouraldein MH. Microbial Etiology of Cancer. Cohesive J Microbiol Infect Dis. 2(4). CJMI.000542.2019.

DOI: 10.31031/CJMI.2019.02.000542

Copyright@ Mosab Nouraldein MH, This article is distributed under the terms of the Creative Commons Attribution 4.0 International License, which permits unrestricted use and redistribution provided that the original author and source are credited.
Mosab Nouraldein $\mathrm{MH}^{*}$

Department of Medical Parasitology, Sudan

\begin{abstract}
Cancer is a very serious health problem affects huge number of people around the globe, up to date there is no known treatment to cancer due to diversity of disease and unknown etiology of cancer. I think that cancer occurrence must be attributed to microbes which person gains after birth. To confirm that theory we should conduct many laboratory and clinical investigations involving large sample size with different age group and various risk factors and then examine the relation between microbe and cancer.
\end{abstract}

Keywords: Cancer; Bacteria; Commensal; Pathogen; Etiology

\section{Introduction}

Cancer is the sickness reasoned by an unrestrained division of atypical cells in a part of the body; these can consequence in tumours; damage to immune system; and other harm that can be lethal. Some forms of cancer result in noticeable growths named tumor; while others such as leukaemia; do not. The majorities of the body's cells have specific roles and fixed life spans. Cell death is part of innate and advantageous phenomenon named apoptosis. A cell gets orders to die so that the body can substitute it with a newer cell that functions better. Cancerous cells are deficient in the constituents that order them to discontinue dividing and to die. Accordingly; they increase in the body using oxygen and nutrients that would regularly feed other cells. Cancerous cells can form tumours; damage the immune system and reason other alterations that stop the body from working on a regular basis.

Cancerous cells may emerge in one part; and then extend through the lymph nodes. Many microbial infections may lead to malignancies if left untreated such as Schistosoma haematobium which may lead to bladder carcinoma; Helicobacter pylori which may cause stomach cancer; Salmonella typhi may lead to gall bladder cancer; Chlamydophila pneumoniae which may lead to lung cancer; Escherichia coli and colon cancer; Streptococcus bovis and colorectal cancer and many viral infections may lead to cancer. I think that cancers occur due to microbial cause either due to infection with pathogenic microbe or due to eradication in number or by changing their normal habitat of normal microbial flora which play an important immunological and physiological role in the human body. Extensive studies about the relationship between microorganism and cancer must be conducted; certainly, the relation about the commensal bacteria and cancer.

Dietary physical, chemical and even psychological reasons may lead affect the normal microbial flora and may lead to cancer after long or short period of time according to the nature and dose of the carcinogen.

Most persons born free from bacteria and free from cancer, so I think that there is an intimate relation between cancer and microorganism; chiefly commensal bacteria. I suggest that any chronic defect in the role of normal flora lead to cancer; to confirm that we must perform concentrated studies involving many persons at different age groups and exposed to various risk factors.

For possible submissions Click below:

\section{Submit Article}

